\title{
DESCRIPTION OF PLATE XXIV.
}

Fig. 1. Ypthima rara (under surface), p. 145.

2. Catochrysops hapalina, ơ (upper surface), p. 148.

3. - 누 (upper and under surface).

4. Teracolus intermissus (upper and under surface), p. 152.

5. Neptis eurymene (upper and under surface), p. 145.

6. Ixias depalpura, ơ (upper and under surface), p. 153.

7. -, 오.

8. Hypanis simplex (upper and" under surface), p. 146.

9. Neptis swinhoei (upper and under surface), p. 145 .

10. Aphnceus bracteatus, 오 (under surface), p. 147.

11. $-\longrightarrow$, (upper surface).

12. Surendra biplagiata (upper surface), p. 147.

13. Terias asphodelus, $\delta$ (upper and under surface), p. 151.

2. Notes on the Zebra met with by the "Speke and Grant" Expedition in Eastern Africa. By Col. J. A. Grant, F.R.S., F.Z.S.

[Received March 22, 1883.]

The question as to what Zebras are met with in various parts of Eastern Africa having been started at a former Meeting by $\mathrm{Mr}$. Sclater's remarks on the so-called Equus grevyi of Shoa, I wish to state that, during our expedition of 1860-63, the late Capt. Speke and $I$ found but one species of Zebra along our route. As regards this animal I am able, through the kindness of Mr. W. Speke, the brother of my late companion, to place before the Meeting the head (see woodcut, p. 176), leg, and tail of one of the Zebras shot during our journey. I have repeatedly examined the Burchell's Zebra living in the Society's Gardens, and found the stripes broad, the general colour more like that of the Wild Donkey of Thibet, the legs to have few or no stripes, and the animal not wellbred-looking; whereas Speke's Zebra, as seen in its wild state and from the specimen before us, has narrow stripes of black covering every inch of its body, head, and legs down to the hoofs, distinctly marked, as if by a tar-brush on a white sheet; the muzzle is black (like the photograph of $\boldsymbol{E}$. grevyi). In a sketch made by me in Africa of an old mare which I had shot, the mane stands erect, the tail is barred as far down as the long hairs, which are fuller in this animal than in either the donkey or the mule. This Zebra is not Burchell's Zebra in my opinion.

I saw this Zebra in herds which varied in numbers from two to nine; and if I add up all the animals seen on the fifteen occasions of $m y$ meeting with them, we shall have seventy-five animals. Eight of these I shot ; two were shot by one of our Cape Mounted Riflemen ; and Speke shot two not included in the above. In all we killed nine horses and three mares, leaving a sufficient stock of sixty-five; but if we consider the wide range they must occupy, we did not meet 
with a fiftieth part of the number then in existence, probably two to three thousand.

We were unable to take its correct height; but when it stood beside the full-sized Sable Antelope, this Zebra was one hand lower. Probably by measuring Speke's head some approximate idea of its height would be obtained.

The proportions of the body are symmetrical, the cannon bone short, the body well-ribbed up like a cob, ears short, legs clean, and hoofs perfect in form. Those which we observed were swift walkers, picking up food fast as they went along, fair trotters, and when cantering and galloping their action was perfectly beautiful. Of course we only saw those that were in good condition and healthy; the more weakly and

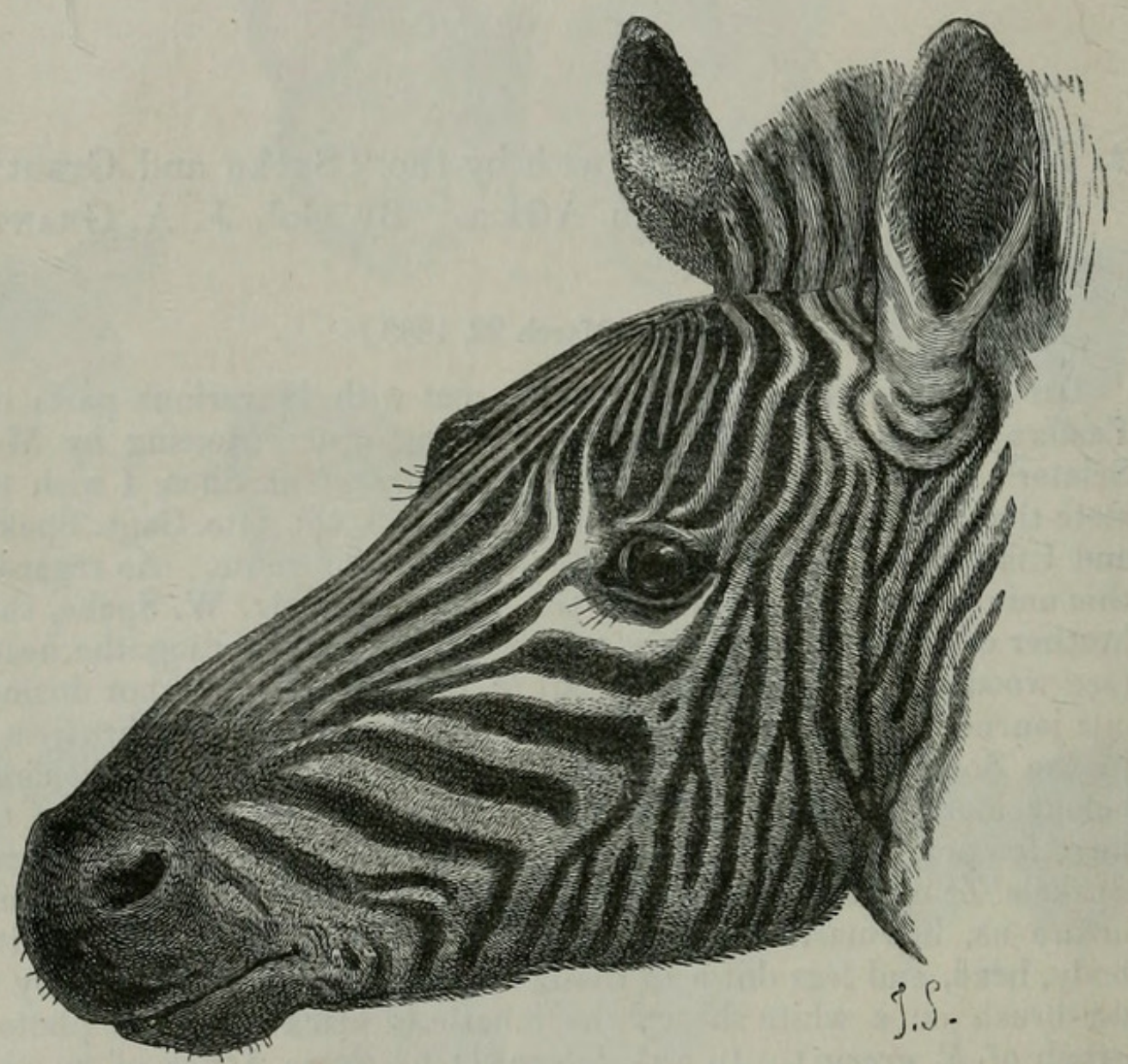

Head of Zebra obtained during the Speke and Grant Expedition.

old no doubt easily fall a prey to numberless Lions, or they may be trapped or speared by natives and shot by travellers. Still I do not think we need in our day despair of having these animals in our Gardens in the Regent's Park.

During our march it was difficult to keep our men provisioned and from craving for meat; and to all of us the sight of a large quarry iterally made every one rejoice; but though the meat of the Zebra is as good in appearance as the finest beef in our markets, it is horsy in flavour, and requires some relish to make it palatable. The meat 
was generally cut into long strips, which were dried to hardness in the sun, and eaten after being frizzled in the fire.

We had not many opportunities of observing the habits of these animals, as they are so wary. One of their number, probably the largest male, takes general charge of the herd; and it was once noticed that a large Antelope kept watch and gave the alarm on our appearance. They are rarely found outside the forest, preferring it to the open plain, which is generally bare of grass; or they frequent a country with clumps of dense brushwood or with outbursts of granite, around which they get abundant food; and they were never seen far from running water and hills.

Their breeding-season was determined by foals following their mothers in the month of January, and by the shrill calls we heard, which came, I presume, from the foals. The first time I heard their call I mistook it for that of a bird, and could scarcely be persuaded till I heard the decided donkey notes following the shriller sounds. They showed much sympathy when a comrade was wounded, lingering with the wounded at the risk of ther lives; they mingled with our laden donkeys one day on the march. And the precautions taken by the leader of the flock of his charge have already been noticed.

We saw that this animal occupies a wide range of country, from the east of the east-coast range of mountains to the north of Lake Nyanza in $0^{\circ} 52^{\prime} \mathrm{N}$. lat., and conclude that, in ground favourable for breeding, it may be found continuously up to Shoa in $10^{\circ} \mathrm{N}$. lat., whence the specimen in the Jardin des Plantes was brought. All this range, however, is not favourable, much of it being mountainous, some being desert and void of water; but altitude does not seem to make material difference. The animal was shot by our party at altitudes ranging from 200 feet above sea-level to three and four thousand feet high, on elevated plateaux covered with forest; at the head-waters of the Mgæta river, which flows into the Kingani, debouching on the east coast, we shot it ; across the east-coast range, near the head-waters of the Nile in E. Ugogo, we saw it; near the shores of Lake Nyanza, in Usui, we found it; and in Uganda, to the north of Victoria Lake, we shot it.

It therefore appears to be a hardy animal, living as it does at such varied altitudes and under such different temperatures, ranging from $70^{\circ}$ night heat to $130^{\circ}$ day. It may also be said of it that the disease which affects the imported mules and horses seems not to destroy it, that it was generally found wherever there is good grazing and where cattle most abound, and that it has chosen for its homes some of the brightest and most fertile spots in Equatorial Africa. 
April 17, 1883.

Prof. Flower, LL.D., F.R.S., President, in the Chair.

The Secretary read the following report on the additions to the Society's Menagerie during the month of March 1883:-

The registered additions to the Society's Menagerie during the month of March were 129 in number. Of these 35 were acquired by presentation, 49 by purchase, 11 were born in the Gardens, and 34 were received on deposit. The total number of departures during the same period, by death and removals, was 120 .

The following are of special interest :-

1. Three Sirens (Siren lacertina) from South Carolina, presented by G. E. Manigault, Esq., C.M.Z.S., March 21st.

2. An American Teetee Monkey, of the genus Callithrix, which it is difficult to determine satisfactorily in its living state, but which is certainly new to the Society's Collection, purchased March 31st.

The Monkey, which was obtained of Mr. Hagenbeck of Hamburg, is about 15 inches in length of body, and has a long slender tail of about the same length. Its fur is of a nearly uniform dirty white; face blackish; hands and feet black; tail pale reddish.

There is no specimen like it in the British Museum; nor can I find any description applicable to it.

3. A Madagascar Lemur, of the genus Hapalemur (probably $H$. griseus), purchased March 31st, also new to the Society's Collection.

The following papers were read:--

1. On the Arrangement of the Orders and Families of existing Mammalia. By William Henry Flower, LL.D., F.R.S., P.Z.S., \&c.

[Received April 17, 1883.]

In the present condition of the world, Mammals have become so broken up into distinct groups by the extinction of intermediate forms, that a systematic classification is perfectly practicable. Most of the associations of species, which we call "orders," and even the "suborders" and "families," are natural groups. In isolating, defining, and naming them, we are really dealing with facts of nature, of a totally different order from the artificial and fanciful divisions formed in the infancy of zoological science. It is therefore worth while to keep their characters and limits constantly in our view, and to test their validity by every advance of knowledge.

When, however, we pass to the extinct world, all is changed. In many cases the boundaries of our groups become enlarged until they touch those of others. New forms are discovered which cannot be placed within any of the existing divisions. As the horizon of our vision is thus expanded, the principles upon which a scheme of classification is constructed must be altogether changed. Our 
present divisions and terminology are no longer sufficient for the purpose; and some other method will have to be invented to show the complex relationships existing between different animal forms when viewed as a whole. The present time, preeminently distinguished by the rapidly changing and advancing knowledge of extinct forms, is scarcely one in which this can be done with any satisfactory result. All attempts to form a classification embracing even the already known extinct species must be only of a very provisional and temporary nature. There are, moreaver, special difficulties in undertaking this subject, to any one working on this side of the Atlantic.

It has often been remarked that the centre of gravity of the civilization, arts, literature, and commerce of the world appears to be shifting westward. This is certainly the case with palæontological discovery. Our knowledge of the ancient condition of animal life on the earth is being revolutionized by explorations in the so-called " New World." With regard to Mammals it is a curious fact, that although research has been prosecuted in suitable localities in many parts of Europe and Asia with considerable assiduity since the beginning of the century, scarcely a single form has been found which does not come within the limits of our actual ordinal groups, or which would necessitate any important modification in a classification based upon existing species. But in the New World, beginning with the earliest known South-American extinct forms-the Toxodons, Nesodons, Mesotheriums, \&c., and passing to the still more wonderful discoveries of the last ten years in the Western Territories of the United States, we find ourselves in completely new realms of life. We are all at once confronted with numerous highly specialized forms, representing apparently new ordinal groups, and still more numerous generalized forms filling up the intervals, and breaking down the distinctions between nearly all the best-established orders of higher placental Mammals. With these I do not propose to deal in the present communication. The very abundance of the material that has lately come to hand is in itself an obstacle to drawing any satisfactory generalizations from it, as it has not left leisure to the few who have an opportunity of working at it to give such full and detailed descriptions as are necessary for the guidance of those who have not the advantage of examining the actual specimens.

In systematic descriptions in books, in lists, and catalogues, and in arranging collections, the objects dealt with must be placed in a single linear series. But by no means whatever can such a series be made to coincide with natural affinities. The artificial character of such an arrangement, the constant violation of all true relationships, are the more painfully evident the greater the knowledge of the real structure and affinities. But the necessity is obvious; and all that can be done is to make such an arrangement as little as possible discordant with facts. In preparing the article "Mammalia" for the ninth edition of the 'Encyclopædia Britannica,' such a scheme had to be framed; and the chief merit which I claim for it is, that it departs as little as possible from the prevailing, or what may be called traditional, sequences of arrangement. In the article, 
which has just appeared in the XVth volume of the ' Encyclopædia,' the groups will be found more fully defined than it is necessary to do here; but it was suggested to me by our Secretary, that it would be desirable to place before the Fellows of the Society, in a more couvenient form, an abstract of the arrangement adopted, preceded by a few explanatory notes upon the mutual relations of some of the principal groups.

One of the most certain and fundamental points in the classification of the Mammalia is, that all the animals now composing the class can be grouped primarily into three natural divisions, which, presenting very marked differential characters, and having no existing, or yet certainly demonstrated extinct, intermediate or transitional forms, may be considered as subclasses of equal value, taxonomically speaking, though very different in the numbers and importance of the animals at present composing them. These three groups are often called by the names originally proposed for them by Blainville-(1) Ornithodelphia, (2) Didelphia, (3) Monodelphiathe first being equivalent to the order Monotremata, the second to the Marsupialia, and the third including all the remaining members of the class. Although actual palæontological proof is wanting, there is much reason to believe that each of these, as now existing, are survivors of distinct branches to which the earliest forms of Mammals have successively given rise, and for which hypothetical branches Professor Huxley has proposed the names of Prototheria, Metatheria, and Eutheria ${ }^{1}$, names which, being far less open to objection than those of Blainville, are here used as equivalents of the latter.

The only known Prototheria, though agreeing in many important characters, evidently represent two very diverging stocks, perhaps as far removed as are the members of some of the accepted orders of the Eutheria. It would, however, be encumbering zoological science with new names to give them any other than the ordinarily known family designations of Ornithorhynchida and Echidnidae.

Similarly with regard to the Metatheria, although the great diversity in external form, in anatomical characters, and in mode of life of the various animals of this section might lead to their division into groups equivalent to the orders of the Eutheria, I do not think it advisable to depart from the usual custom of treating them all as forming one order, called Marsupialia, the limits of which are equivalent to those of the subclass, and the primary divisions of which are called "families." The limits of these six families are extremely well marked and easily defined; and as they form a regular gradation between two extreme types, they can be satisfactorily arranged in a serial order.

The remaining Mammals are included in the Eutheria, Placentalia or Monodelphia. Their affinities with one another are so complex that it is impossible to arrange them serially with any regard to natural affinities. Indeed each order is now so isolated that it is almost impossible to say what its affinities are; and none of the hitherto proposed associations of the orders into larger groups

$$
{ }^{1} \text { P.Z.S. } 1880 \text {, p. } 649 .
$$


stand the test of critical investigation. All serial arrangements of the orders are therefore perfectly arbitrary; and although it would be of very great convenience for reference in books and museums if some general sequence, such as that here proposed, were generally adopted, such a result can scarcely be expected, as equally good reasons might be given for almost any other combination of the various elements of which the series is composed. In fact I have already seen reason to depart in some respects from that used in the 'Encyclopædia.'

The Edentata, Sirenia, and Cetacea stand apart from all the rest in the fact that their dentition does not conform to the general heterodont, diphyodont type to which that of all other Eutheria can be reduced, and which is such a close bond of union between them. In all three orders, however, some indications may be traced of relationship, however distant, with the general type.

I must refer to a paper communicated to the Society last year for my riews as to the grouping of the animals composing the Edentata, which differ from those of most, if not all, zoologists who have previously made them their study ${ }^{1}$. I there gave reasons for believing that the Sloths and Anteaters were nearly related, and that the Armadillos, though much modified, belonged to the same stock, but that the Pangolins and the Orycteropus each represented very isolated forms. The division of the order into four suborders here proposed is an attempt to represent these views, though not altogether satisfactory, as the present divergence between the first two families is scarcely sufficiently indicated by their association in one suborder.

There is no difficulty about the limits of the order Sirenia, composed of aquatic, vegetable-eating animals, with complete absence of hind limbs, and low cerebral organization, represented in our present state of knowledge by but two existing genera, Halicore and Manatus, and a few extinct forms, which, though approaching a more generalized mammalian type, show no special characters allying them to any of the other orders. The few facts as yet collected relating to the former history of the Sirenia leave us as much in the dark as to the origin and affinities of this peculiar group of animals as we were when we only knew the living members. They lend no countenance to their association with the Cetacea ; and, on the other hand, their supposed affinity with the Ungulata receives no very material support from them.

Another equally well-marked and equally isolated, though far more numerously represented and diversified order, is that of the Cetacea, placed simply for convenience next to the Sirenia; for except in their fish-like adaptation to aquatic life they have little in common with them. The old association of these orders in one group can only be maintained either in ignorance of their structure or in an avowedly artificial system. Among the existing members of the order, there are two very distinct types, the toothed Whales or Odontoceti, and the Baleen Whales or Mystacoceti, which present as many marked distinguishing structural characters as are found between many other divisions of the Mammalia which are

$$
{ }^{1} \text { P. Z.S. } 1882 \text {, p. } 358 \text {. }
$$


reckoned as orders. As the extinct Zeuglodon, as far as its characters are known, does not fall into either of these groups, but is in some respects an annectent form, I have placed it provisionally, at least, in a third group by itself, named Archceoceti. There is nothing: known at present to connect the Cetacea with any other order of Mammals ; but it is quite as likely that they are offsets of a primitive Ungulate as of a Carnivorous type ${ }^{1}$.

The remaining Eutherian Mammals are clearly united by the characters of their teeth, being all heterodont and diphyodont, with their dental system traceable to a common formula.

Although older views of the relationship of Ungulate Mammals expressed by the terms Pachydermata, Ruminantia, and so forth, still linger in some corners of zoological literature, no single point in zoological classification can be considered so firmly established as the distinction between the Perissodactyle and Artiodactyle Ungulates, both perfectly natural and distinctly circumscribed groups. The breaking-up of the latter into four equivalent sections, the Pecora, Tylopoda, Tragulina, and Suina, is equally in accordance with all known facts. Less certain; however, is the association of the Proboscidea and the Hyracoidea with the true Ungulates. By many they are each, although containing so very few existing species, made into distinct orders; and much is to be said in favour of this view. The discovery, however, of a vast number of extinct species of Ungulates which cannot be brought under the definition of either Perissodactyle or Artiodactyle, and yet are evidently allied to both, and which to a certain extent bridge over the interval between them and the isolated groups just mentioned, make it necessary either to introduce a number of new and ill-defined ordinal divisions, or to widen the scope of the original order so as to embrace them all, considering the Elephants and the Hyraces as representing suborders equivalent to the great Perissodactyle and Artiodactyle groups. It is the latter alternative that $I$ have adopted.

In the association of the three orders Insectivora, Cheiroptera, and Rodentia, and in their subdivisions, I have followed Mr. Dobson's article in the 'Encyclopædia.' They appear to resemble each other in presenting a lower type of placentation to that of the other Eutherians, shown in the important part played by the umbilical vesicle, which becomes adherent to a considerable part of the inner surface of the chorion and conveys bloodvessels to it ; but the few observations hitherto made upon this subject require to be confirmed and extended before it will be safe to attach much weight to them. This and other cranial and cerebral characters indicate that they occupy an inferior grade of development in the Mammalian series; but there are difficulties in interposing them in any other position than that assigned to them here, which must not be supposed to imply any superiority over the groups placed below them, but rather that they occupy a central position, connected, as palæon-

${ }^{1}$ On the question of the origin and affinities of the Cetacea, see a lecture delivered at the Royal Institution of Great Britain, May 25th, 1883, and published in 'Nature,' June 28th and July 5th, 1883. 
tology seems to show, with the Carnivora on the one hand and the Ungulata on the other. In the 'Encyclopædia' they were placed at the bottom of the diphyodonts, between the Cetacea and the Ungulates; but this had the disadvantage of widely separating these probably allied groups, and of removing the Insectivora entirely from the Carnivora, with which they form a somewhat natural sequence.

The Chiroptera have always been placed near the Insectivora; but they are really a highly specialized group, as much isolated from all other Mammals by the modification of their anterior limbs in adaptation to aerial locomotion, as the Cetacea and the Sirenia, by the absence of hind limbs, are specially adapted to aquatic life. The Rodentia, though generally presenting a low grade of development, are also a specialized group. The position here assigned to them would accord with apparent relationships with the Ungulates, through the Elephant on the one hand, and the extinct Mesotherium on the other.

In the present state of the fauna of the earth, the Carnivora form a very distinct order, though naturally subdivided into two groups, the members of the one being more typical, while the other (the Pinnipedia) are aberrant, having the whole of their organization specially modified for living habitually in the water.

Lastly, the Primates, which in any natural system must be placed at the head of the series, are divisible into two very distinct groups-one containing the various forms of Lemurs (Lemuroidea), and the other containing the Monkeys and Man (Anthropoidea). Whether the Lemuroidea should form part of the Primates (according to the traditional view), or a distinct order altogether removed from it, is as yet an undetermined question, for both sides of which there is much to be said. There can, however, be no doubt that the Anthropoidea form a perfectly natural group, presenting a series of tolerably regular gradations from the Marmosets (Hapale) to Man. Certain breaks in the series, however, enable us to divide it into five distinct families :-Hapalidae or Marmosets; Cebida or American Monkeys, with three premolar teeth on each side of each jaw; Cercopithecida, containing the majority of Old-world Monkeys; Simiida, consisting of the genera Hylobates, Simia, Gorilla, and Troglodytes, the true Man-like Apes; and, lastly, Hominidee, containing the genus Homo alone.

Orders, Suborders, and Families of existing Mammals.

Subclass PROTOTHERIA or Ornithodelphia.

Order MONOTREMATA.

Ornithorhynchidæ.

Echidnidæ.

Proc. Zool. Soc.-1883, No. XIII. 
Subclass METATHERIA or Didelphia.

\section{Order MARSUPIALIA.}
Didelphidæ.
Dasyuridæ.
Peramelidæ.
Macropodidæ.
Phalangistidæ.
Phascolomyidæ.

Subclass EUTHERIA or Monodelphia.

\section{Order EDEINTATA.}

Suborder PILOSA.

Bradypodidæ.

Myrmecophagidæ.

Suborder LORICATA.

Dasypodidæ.

Suborder SQUAMATA.

Manidæ.

Suborder TUBULIDENTATA.

Order SIREINIA.

Orycteropodidæ.

Order CETACEA.

Manatidæ.

Halicoridæ.

Suborder MYSTACOCETI.

Balænidæ.

Suborder ODONTOCETI.

Physeteridæ.

Platanistidæ.

Order UNGULATA.

Delphinidæ.

Suborder ARTIODACTYLA.

Suina.

Hippopotamidæ.

Phacochœridæ.

Suidæ.

Dicotylidæ.

Tragulina.

Tragulidæ.

TylOPODA.

Camelidæ. 
Pecora.

Cervidæ.

Giraffidæ.

Antilocapridæ.

Bovidæ.

Suborder PERISSODACTYLA.

Equidæ.

Tapiridæ.

Rhinocerotidæ.

Suborder HYRACOIDEA.

Hyracidæ.

Suborder PROBOSCIDEA.

Elephantidæ.

Order RODENTIA.

Suborder SIMPLICIDENTATA.

Anomaluridæ.

Sciuridæ.

Haplodontidæ.

Castoridæ.

Myoxidæ.

Lophiomyidæ.

Muridæ.

Spalacidæ.

Geomyidæ.

Dipodidæ.

Octodontidæ.

Hystricidæ.

Chinchillidæ.

Dinomyidæ.

Caviidæ.

Suborder DUPLICIDENTATA.

Lagomyidæ.

Leporidæ.

Order CHIROPTERA.

Suborder MEGACHIROPTERA.

Pteropodidæ.

Suborder MICROCHIROPTERA.

Vespertilionidæ.

Nycteridæ.

Rhinolophidæ.

Emballonuridæ.

Phyllostomidæ. 


\section{Order INSECTIVORA.}

Suborder DERMOPTERA.

Galeopithecidæ.

Suborder INSECTIVORA VERA.

Tupaiidæ.

Macroscelidæ.

Erinaceidæ.

Soricidæ.

Talpidæ.

Potamogalidæ.

Solenodontidæ.

Centetidæ.

Order CARINIVORA.

Chrysochloridæ.

Suborder PINNIPEDIA.

Phocidæ.

Trichechidæ.

Otariidæ.

Suborder CARNIVORA VERA or Fissipedia. Arctoldea.

Ursidæ.

Ailuridæ.

Procyonidæ.

Mustelidæ.

Cynoidea.

Canidæ.

Elluroidea.

Hyænidæ.

Protelidæ.

Viverridæ.

Felidæ.

Order PRIMATES.

Suborder LEMUROIDE.A.

Chiromyidæ.

Tarsiidæ.

Lemuridæ.

Suborder ANTHROPOIDEA.

Hapalidæ.

Cebidæ.

Cercopithecidæ.

Simiidæ.

Hominidæ. 


\section{$2 \mathrm{BHL}$ Biodiversity Heritage Library}

Grant, J A. 1883. "Notes on the Zebra met with by the "Speke and Grant" Expedition in Eastern Africa." Proceedings of the Zoological Society of London 1883, 175-186. https://doi.org/10.1111/j.1469-7998.1883.tb06648.x.

View This Item Online: https://www.biodiversitylibrary.org/item/96834

DOI: https://doi.org/10.1111/j.1469-7998.1883.tb06648.x

Permalink: https://www.biodiversitylibrary.org/partpdf/73189

\section{Holding Institution}

Natural History Museum Library, London

\section{Sponsored by}

Natural History Museum Library, London

\section{Copyright \& Reuse}

Copyright Status: Public domain. The BHL considers that this work is no longer under copyright protection.

This document was created from content at the Biodiversity Heritage Library, the world's largest open access digital library for biodiversity literature and archives. Visit BHL at https://www.biodiversitylibrary.org. 